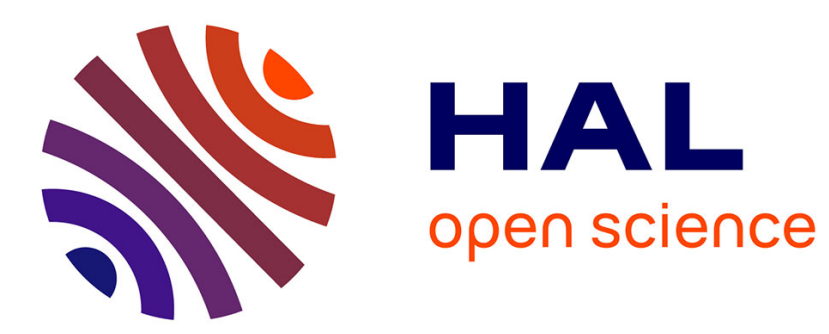

\title{
In or out? Organisational dynamics within European 'peasant seed' movements facing opening-up institutions and policies
}

\author{
Elise Demeulenaere, Yvonne Piersante
}

\section{To cite this version:}

Elise Demeulenaere, Yvonne Piersante. In or out? Organisational dynamics within European 'peasant seed' movements facing opening-up institutions and policies. Journal of Peasant Studies, 2020, Forum on Seed activism, 47 (4), pp.767-791. 10.1080/03066150.2020.1753704 . hal-03005880

\section{HAL Id: hal-03005880 \\ https://hal.science/hal-03005880}

Submitted on 19 Jun 2021

HAL is a multi-disciplinary open access archive for the deposit and dissemination of scientific research documents, whether they are published or not. The documents may come from teaching and research institutions in France or abroad, or from public or private research centers.
L'archive ouverte pluridisciplinaire HAL, est destinée au dépôt et à la diffusion de documents scientifiques de niveau recherche, publiés ou non, émanant des établissements d'enseignement et de recherche français ou étrangers, des laboratoires publics ou privés. 


\section{The Journal of Peasant Studies}

\section{In or out? Organisational dynamics within European 'peasant seed' movements facing opening-up institutions and policies}

\section{Elise Demeulenaere \& Yvonne Piersante}

To cite this article: Elise Demeulenaere \& Yvonne Piersante (2020): In or out? Organisational dynamics within European 'peasant seed' movements facing opening-up institutions and policies, The Journal of Peasant Studies, DOI: 10.1080/03066150.2020.1753704

To link to this article: https://doi.org/10.1080/03066150.2020.1753704

\section{曲 Published online: 13 May 2020.}

Submit your article to this journal $\widetilde{ }$

$$
\text { Џlll Article views: } 1
$$

\section{Q View related articles $₫$}

\section{View Crossmark data ¿}




\title{
In or out? Organisational dynamics within European 'peasant seed' movements facing opening-up institutions and policies
}

\author{
Elise Demeulenaere ${ }^{a}$ and Yvonne Piersante ${ }^{b}$ \\ ${ }^{a}$ Centre Alexandre Koyré, National Centre for Scientific Research (CNRS), Paris, France; ${ }^{b}$ University of Calabria, \\ Arcavacata di Rende, Italy
}

\begin{abstract}
This paper explores the organisational dynamics of movements claiming for a peasant reappropriation of seeds, in a context where genetic resources issued from Participatory Plant Breeding programmes involving farmers are getting official recognition from the European Union. The two organisations in France and Italy under scrutiny illustrate different pathways in seed activism. Drawing on Kriesi's framework, we interpret them as trajectories of institutionalisation, commercialisation, and conviviality. Whether or not seed activists should attempt to change the world from within institutions or from outside is highly disputed. It leads up to the connected issue of social base participation and internal democracy.
\end{abstract}

\section{KEYWORDS}

Seed activism; social movement organisations; peasant seeds; institutionalisation; commons; expertise; participation

In the beginning of the 2000s, several movements claiming for a farmers' reappropriation of seeds have emerged in Europe. This took place in contexts where agriculture had been deeply transformed by several-decade modernisation policies. ${ }^{1}$ Bearing a unilinear vision of progress, including a search for productivity and standardisation processes, modernisation relies on techno-scientific innovations spearheaded by agronomists, which farmers are expected to embrace. In the domain of plant breeding, farmers have been encouraged, both by extension services and seed laws, to adopt high-yielding and genetically uniform varieties at the expenses of heritage varieties and landraces - which are usually 'varietypopulations', to borrow from genetics vocabulary, i.e. rather heterogeneous. Besides, for various reasons (technical, social, legal), ${ }^{2}$ a majority of farmers have progressively dropped of out on-farm seed saving practices, and turned to the annual purchase of certified seeds. As a result, landraces have progressively vanished from farms together with on-farm plant breeding and seed management practices. At the turn of the

CONTACT Elise Demeulenaere elise.demeulenaere@mnhn.fr $\Theta$ Centre Alexandre Koyré, 27 Rue Damesme, 75013 Paris, France

Editorial Note: This article is part of the 'Forum on Seed Activism' guested edited by Karine Peschard and Shalini Randeria.

${ }^{1}$ Such transformation has been more recent and rapid, and may still be incomplete, in former Soviet countries, which have more recently integrated the European Union.

${ }^{2}$ We cannot go into the detail of each national legal framework but we must at least mention that newly bred plant varieties are ruled in Europe by the International Union for the Protection of New Varieties of Plants, known as UPOV and set up in 1961. The 1991 version of the UPOV Convention restricted the farmers' privilege to resow seed harvested from protected varieties for their own use (Dutfield 2018, 28-29). Such provision has been incorporated in European law through the European Regulation CE 2001/1994.

(c) 2020 Informa UK Limited, trading as Taylor \& Francis Group 
century, alternative farmers who wanted to revive landraces and on-farm plant breeding practices faced legal and practical lock-ins: laws restricting seed marketing and exchange to varieties registered on an official catalogue, which requires that the variety meets 'Distinctiveness, Uniformity, Stability' (DUS) requirements; difficulty to find even out of commercial circuits seed lots from these landraces; loss of knowledge and know-how.

Three organisations in Europe have raised particular attention, for their level of development and for their strong anchoring within the farming world (as opposed to gardeners' or citizens' associations): Red de semillas in Spain, Réseau semences paysannes in France, and Rete Semi Rurali in Italy (Bocci and Chable 2009; Corrado 2010; Da Vià 2012; Balázs et al. 2015). We see these national organisations as 'new agrarian movements' (Piersante 2019), in that they derive from coalitions of farmers' mobilizations and civil society organisations engaged in food and environmental issues, and claim values that are not based on class issues but on qualitative and non-negotiable principles. Like the transnational agrarian movements (TAMs) that have established themselves in recent decades around the 'new agricultural food issue' (McMichael 2008) against the neoliberal development model (Borras and Franco 2009; Martínez-Torres and Rosset 2010), these organisations have succeeded in linking food quality, farmers' autonomy vis-à-vis agri-food, rural development and biodiversity management issues. They have been interpreted as taking part in a wider dynamics of 'repeasantisation' (Van der Ploeg 2010), in the sense that they articulate differentiation, innovation, decommodification, reappropriation and readaptation of technology in order to reach autonomous reproduction of small-scale farming (Corrado 2010; Da Vià 2012).

Other studies have focused on the innovative nature of these organisations, which, much like TAMs in recent decades, have created important cross-class and cross-sectorial synergies with other social movements, from environmentalists to food and human rights movements - by sharing campaigns on broker issues, drawing on existing identity resources or reinventing them (Edelman and Borras 2016). In particular, certain texts have analysed the paradigm shift introduced in French by the invention of the category semences paysannes (literally 'peasant seeds', at the heart of the identity of the Réseau Semences Paysannes) in an effort to distinguish oneself from semences de ferme (i.e. farm-saved seeds) (Demeulenaere 2014). The latter category designates seeds reproduced on the farm, which are in industrialised farming contexts by default seeds from improved varieties (pure lines, F1 hybrids, GMOs ...) not adapted to organic farming. The former differs both in terms of the genetic quality of the seeds and in terms of the political dimension it takes on: peasant seeds indeed refer to seeds produced and bred from generation to generation by farmers and gardeners on their farms, presenting certain characteristics, such as genetic heterogeneity (geneticists speak of 'variety-populations' or simply 'populations' as opposed to uniform and stable modern varieties), great adaptability to variable environments, the mark of their cultivation history and the absence of property rights. Noteworthy enough, the expression semences paysannes has been adopted by the French organisation from 2003 onwards but its translation in English as 'peasant seeds' has stabilised fairly recently. The first translations in English referred to 'farmers' seeds' probably because the term peasant doesn't have the same history in English as in French, with the consequence of confusing it with farm-saved seeds (Demeulenaere 2014).

This paper analyses an aspect that has not been discussed so far, i.e. the relations that these organisations forge with public institutions. The positioning of farmers' seed 
movements towards institutions is all the more interesting to follow as peasant seeds in Europe are currently gaining formal recognition in European policies. Whereas these movements struggled for years to end the legal exclusion of peasant seeds - too heterogeneous to be registered in the official catalogue of protected varieties, which is a prerequisite to get marketing authorisation - in 2014 the European Commission started a temporary experiment circumventing the catalogue: it provided derogations for some plant species (wheat, barley, oats and maize) authorising the marketing of heterogeneous 'populations' (EU Decision 2014/150). Lately a regulation on organic production allows operators 'to market plant reproductive material of organic heterogeneous material' without having to comply with classic registration requirements (EU Regulation 2018/ 848, to be implemented after 2021). Both legal categories 'populations' and 'heterogeneous material' include the relatively heterogeneous varieties developed on-farm by collectives of farmers or in the context of Participation Plant Breeding ${ }^{3}$ (PPB) programmes. As Brussels seems prepared to include heterogeneous populations in the new seed regulation to be discussed in 2021, interesting questions arise: To what extent these organisations advocating for peasant seeds have tried to drive these legal changes? How do they respond to these opening-up institutions and policies and reposition themselves?

Relationships with institutions is an important focus of social movement theory. Social movements have long been regarded as necessarily grassroots, thriving outside institutions, and contesting 'the instituted.' At some point they can become 'instituting' depending on the capacity of institutions to integrate their criticisms - or in academic words, the degree of openness of the 'political opportunity structure' (Tarrow 1989). These debates are all the more topical as in recent decades European democracies have experimented with forms of decision-making relying on devices meant to better take into account various stakeholders' views, and for particularly complex issues, to integrate specific professional expertise (Giddens 1990; Callon, Lascoumes, and Barthe 2009). In the sector of genetic resources and biotechnological innovations, discussion forums (such as scenario workshops, consensus conferences, etc.) which allow for deliberative participation models have flourished (Pellizzoni 1999). Some social movement organisations saw this as an opportunity to lobby from inside the institutions. At the same time, it opened up disputes between the constellation of actors that fuel social movements as well as academic debates on whether or not such inclusive policies were a means for powers to tame critique (Topçu, Gourgues, and Rui 2013). In the case of GM plant controversy in France, it has been observed that anti-GM activists have been able to articulate two types of criticism: 'radical criticism', from outside the system, and 'regulatory criticism' (critique de régulation), from within the system (Chateauraynaud et al. 2010). Relations with institutions have also attracted the attention of analysts of transnational agrarian movements. Borras and Franco note that La Vía Campesina, for example, has been very active in carving out its own space for participation and representation in global governance processes and institutions (Borras and Franco 2009, 28). In turn, Martínez-Torres and

\footnotetext{
${ }^{3}$ Participatory Plant Breeding is a decentralized, transdisciplinary and multi-actor process of plants selection, commonly based on collaborations between farmers and breeders (geneticists and agronomists). It usually leads to genetically heterogeneous materials - that is plant varieties that are not distinct, uniform and stable (the so-called DUS criteria required for the registration and commercialitation of seeds) - more adapted to the characteristics of the territory, to agro-ecological cultivation practices and to the needs of the farmers who have selected them (Ceccarelli and Grando 2007; Dawson et al. 2011).
} 


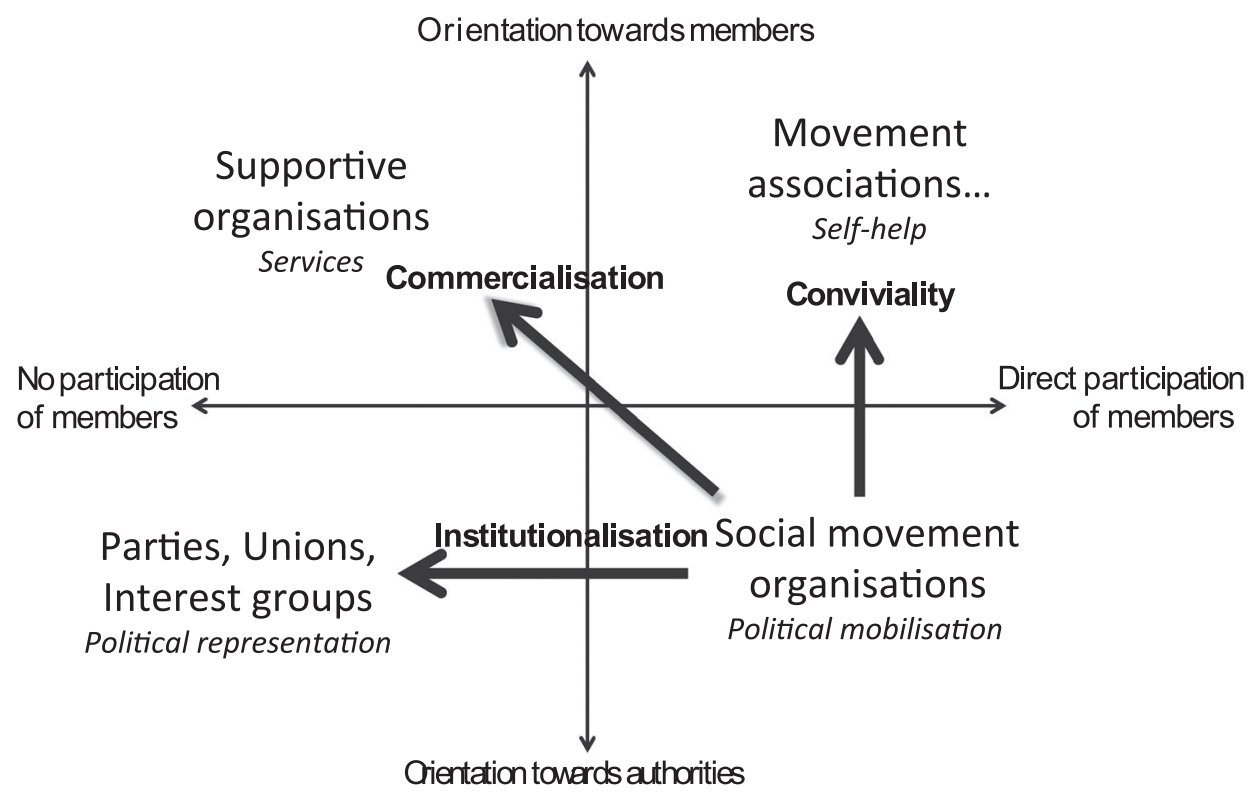

Figure 1. Typology of social movement-related organisations, and possible transformations of their goal orientations and action repertoires (from Kriesi 1996 and Neveu 2015).

Rosset (2010) highlight the Vía Campesina's dual strategy - 'outside' and 'inside' - pointing to the possibility of multiple strategic choices that evolve over time, an issue which will be at the heart of this article. ${ }^{4}$

In his attempt to draw up a typology of organisations participating in the social movement (broadly defined as forms of collective action oriented towards a specific claim), political scientist Hanspeter Kriesi introduced another dimension, namely the level of participation of the constituency. Organisations can be represented on a plan, along two axes, and typified in 4 categories (Figure 1):

(1) Social Movement organizations s.S., which mobilise their members for collective action and do so with a political goal, to obtain collective good (avoid collective ill) from authorities.

(2) Supportive organizations, i.e. service organisations, such as friendly media, churches, restaurants, print shops ...

(3) Movement associations, such as self-help, voluntary associations, clubs ... aiming to cater to some daily needs of their members.

(4) Parties and interest groups, which do not depend on the direct participation of the constituency. They are specialised in political representation. Their main resource is institutionalised access, authority, expertise.

Kriesi's theoretical framework can also be used to analyse the trajectories of social movement organisations over time. The evolution from a classic social

\footnotetext{
${ }^{4}$ 'The political tactics of La Vía Campesina are more 'outside' than 'inside', and protest than lobby, though La Vía Campesina does sometimes engage in coordinated inside-outside strategies with its allies and does lobby' (Martínez-Torres and Rosset 2010, 163).
} 
movement organisation to an interest group is referred to as an 'institutionalisation' trajectory. The development of marketed services without any participation of the social base is called 'commercialisation'. The scenario in which a social movement organisation deserts institutional arenas to turn exclusively to its social base is called 'involution' or, in the presentation of Kriesi's work by Erik Neveu, 'conviviality' (Neveu 2015, 26).

In order to analyse dynamics of organisations related to peasant seed activism in the current context, we adopted a comparative, longitudinal approach, with two case studies from France and Italy examined over a 20-year period. The two organisations we propose to study are the French Peasant Seeds Network (Réseau Semences Paysannes - RSP) and the Italian Rural Seeds Network (Rete Semi Rurali - RSR). They arose in France and Italy respectively at the beginning of the 2000s. Both result from the networking of heterogeneous actors, including farmers' organisations, trade unions, non-profit organisations, small seed companies, artisans, international environmental or solidarity associations and actors involved in the alternative agrifood chain. Both promote farmers' rights to manage, produce and promote crop biodiversity on farms. Both have fostered peer-to-peer exchanges, from the local level to the international level, participating since 2005 in several gatherings at the European level, which paved the way for the creation in 2012 of the European Coordination Let's Liberate Diversity! (EC-LLD!).

Our choice to focus on the French and Italian seed organisations was initially motivated in part by our good knowledge of the two cases. ${ }^{5}$ As we will see, the comparison appears even more relevant a posteriori. Indeed, despite their similarities and connections, the two movements draw distinct trajectories as regards their relationships with institutions and with their basis, illustrating different pathways in farmers' seed activism towards institutionalisation.

\section{The French peasant seeds network: from a pluralist and flexible strategy, including investing institutions, to recentring on fieldwork}

The Peasant Seeds Network (hereinafter RSP) was founded with the legal status of a French registered association in 2003. It currently has around ninety collective members, who use their practices and discourses to promote 'peasant seeds', i.e. seeds that are not only produced but also bred on farms by farmers' collectives. The network is in favour of the re-appropriation of seeds by farmers in the name of farmers' sovereignty and the stewardship of agrobiodiversity. The following section details the context in which the organisation was born and its strategy during its first 15 years, up to a recent reorientation discussed within the RSP and finally voted by the General Assembly.

\footnotetext{
${ }^{5}$ E. Demeulenaere has followed the French Peasant Seeds Network since 2005, both as an ethnographer and a regular member. Y. Piersante has worked in 2008-2009 for Crocevia, one of the founding associations of the Italian Rural Seeds Network, and is a member of the Board since 2012. In the frame of her PhD, which proposed a comparative study of the French and the Italian seed movements, she has conducted about thirty-five interviews. Our analysis draws on these interviews, as well as on participant observations in annual general meetings, working groups, field trial visits, roundtables and public events, on written documents produced by both movements, and finally on the critical feedback we received from our interviewees.
} 


\section{At the origins of the peasant seeds network}

The creation of the RSP took place after a decade of struggles against GMOs (genetically modified organisms), spearheaded both by the environmental NGO Greenpeace and the left-wing farmers' union Peasant Confederation (Confédération paysanne). Created in France in 1987 as a new avatar of the 1970s farmers' movements calling for alternatives to the modernisation of agriculture, 'La Conf', as it has been nicknamed, gained huge momentum in the 1990s thanks to its strategic opening up to a larger public, aware that its defence of 'peasant agriculture' (agriculture paysanne) would have more impetus if it were to be connected to other public interest issues such as environmental protection, healthy food, fair trade and international solidarity (Morena 2015). The association Friends of the Peasant Confederation (Les Amis de la Conf) was created to welcome the support of all those (including non-farmers) who sympathised with the political orientation of the farmers' union. Its figurehead Jové Bové became famous for his fight against junk food (malbouffe), epitomised by a protest campaign against a McDonald's restaurant under construction in Millau, the region where Roquefort cheese is produced. Bové was sent to jail and thousands of 'alternative globalists' (altermondialistes) demonstrated in Millau to support him before his trial. Meanwhile the anti-GM struggle was progressively reframed from risk to defence of food quality, through critique of productivist agriculture, cultural homogenisation and globalisation; from scientific expertise to 'paysan' expertise (Heller 2002). At the end of the 1990s, anti-GMO activists had already won some important battles. Among their ranks on the farmers' side, some were starting to think of the following step and look for which positive alternatives should be promoted if GMOs were definitively banned from France.

This period was also characterised by a long, latent conflict between the French State and farmers defending seed saving. Saving seeds from protected varieties had been banned by a French law dating from 1970, but the ban had never been enforced. The fear harboured by farmers concerning the enforcement of this law had led to the creation at the end of the 1980s of the National Coordination in Defence of Farm-Saved Seeds (Coordination Nationale de Défense des Semences de Ferme - CNDSF). The issue had become so sensitive that, at the beginning of the 2000s, France was still delaying the incorporation in French law of UPOV 1991 provisions. $^{6}$

Lastly, a European regulation concerning organic agriculture was drafted during the course of 2002. It stipulated that organic farmers would have to provide evidence that the seeds they used were produced according to organic specifications. This requirement would indirectly oblige organic farmers to use certified seeds, and this would in turn dramatically limit the range of varieties available to them, for they are necessarily from varieties registered in the Official Catalogue. As already said, these registered varieties must meet certain characteristics such as genetic homogeneity, and for agricultural crops, high productivity in high-input environments. However, organic farmers often prefer to source their seeds from alternative circuits where the varieties are more diverse and more adapted to low-input farming environments.

When interviewed, the main players involved in the RSP highlighted the importance of individuals wearing several hats, which enabled them to connect different networks and 
issues at various levels (local, national, international). ${ }^{7}$ A notable example is the prominent figure of French seed activism, Guy Kastler. Born in 1950, he developed a solid Marxist political culture as a student, and later became a farmer with a strong interest in biodynamic agriculture. ${ }^{8}$ He dedicated his political commitment to structuring organic agriculture and defending small farmers' interests and worldviews, whilst specialising in seed issues. He was a member of the Peasant Confederation as well as being on the board of a technical institute for organic agriculture (ITAB). In the beginning of the 2000s, he was remunerated for $30 \%$ of his time by Nature \& Progrès, a pioneering movement for organic agriculture in France, to implement the Participatory Guarantee System (SPG), an alternative to certification that would be promoted 10 years later by the International Federation of Organic Agriculture Movements (IFOAM), before he specialised in seed issues. Other actors played a significant role in activating their skills and social capital, even though they remained less visible. The then spokesman of the CNDSF had also been the first spokesman of the Peasant Confederation. He had spent most of his life involved in cooperation in African countries and had a good knowledge of small family farms in the Global South. The agronomist then in charge of these issues at the French Federation for Organic Agriculture (FNAB) also had strong connections to IFOAM. The founder of BEDE, ${ }^{9}$ an NGO dedicated to protecting and promoting small-scale farming in North and West African countries was a geneticist by training who had left a career in research. He was involved in various NGOs which were critical of modern agriculture, and was about to create Inf'OGM, an association whose aim was to strengthen an informed critique of GMOs from the grassroots, through which he met Kastler. At that time, this activist was also on the board of the international NGO GRAIN which brought together a number of researchers with close political links to La Vía Campesina.

When the EU regulation on organic agriculture came under discussion, the aforementioned players convened a meeting to discuss a common strategy. The idea of founding a movement to promote and enhance the visibility of seeds produced and bred on farms, especially in organic farming networks, gained ground. As Kastler recalls, 'We suddenly had the opportunity in France to address seed issues with the three main players in the field: small farmers' unions, organic agriculture networks and NGOs' (interview, February 2018).

More pragmatically, the task of drawing up an inventory of alternative practices to the simple purchase of certified seeds of improved varieties was entrusted to a recently graduated Spanish agronomist following her unsolicited application in 2002. During the course of one year, she investigated the regional structures of organic and biodynamic agriculture and of farmers' unions to collect contacts. She met with several farmers who produced their own seeds or bred their own varieties. The document she submitted in January 2003 was entitled 'A survey of the experiences and know-how relating to "Farmers, organic and biodynamic seeds" in French regions' (Carrascosa 2003). One month later, the 'First meeting on Peasant Seeds' (Premières rencontres Semences

\footnotetext{
${ }^{7}$ The importance of multiple affiliations in the emergence of networks supporting new causes has been commented on by della Porta and Diani (1999).

${ }^{8}$ Biodynamic is an holistic approach to farming inspired by the 1924 lectures to farmers given by anthroposophist Rudolf Steiner calling for a new way to integrate scientific understanding with a recognition of spirit in nature.

${ }^{9}$ Biodiversité Echanges et Diffusion d'Expériences, literally 'Biodiversity, Exchanges and Experience Diffusion.'
} 
Paysannes) was organised in Auzeville in the suburb of Toulouse (South-West of France), ratifying the choice for 'peasant seeds' as a flag of the movement. The meeting, which brought together representatives of the organisations concerned as well as the farmers met by Carrascosa during her survey, is generally considered as the founding event of the RSP.

The legal association was created a few months later, during the summer 2003. According to its original by-laws, the RSP had four founding members: the aforementioned Peasant Confederation, plus three associations for the defence of organic or biodynamic agriculture, namely Nature \& Progrès, a pioneering player in the development of organic agriculture in France; the French Federation for Organic Agriculture (FNAB); and the Movement for Biodynamic Agriculture (MABD). Associations promoting the conservation of cultivated biodiversity (Fruits oubliés, Croqueurs de pommes, etc.) rapidly joined the cause as simple members of the network. The special status dedicated to these four founding members was intended to give more weight to farmers' union and organisations compared to other bodies. The name chosen (Semences paysannes) notably bears the identity mark of the Peasant Confederation, and the alternative farming model it defends, namely peasant agriculture.

At the time of its establishment, the network's main claim was to defend farmers' rights to cultivate and exchange seed varieties that are not included in the official catalogue. Political lobbying was upheld by practical fieldwork to build farmers' collective capacities to maintain and enrich agrobiodiversity. Seed lots from traditional and regional landraces were taken out of gene banks, circulated and cultivated. This new category - 'peasant seeds' - gradually developed a special significance. It included the kinds of seeds produced and bred on farms from generation to generation by farmers, featuring certain traits, such as being genetically heterogeneous (geneticists speak of 'variety populations', or simply 'populations' as opposed to uniform and stable modern varieties), highly adaptable to changing environments, bearing the mark of their cultivation history and being devoid of property rights. ${ }^{10}$ In this sense, the RSP brought to the fore a new category clearly distinct from 'farm-saved seeds.' From then on the designation 'farm-saved seeds' was kept for seeds from improved varieties multiplied on farm for one or a couple of years, a period which does not allow them to significantly differ from the original variety.

As Kastler recalls,

Moving from farm-saved seeds to peasant seeds has been a historical step. It happened in France. Today, the concept of peasant seeds in English is beginning to make its way into FAO's vocabulary. It is not because we are smarter than others; it is simply because we were the right people at the right time. ${ }^{11}$ (interview with Guy Kastler, February 2018)

\footnotetext{
${ }^{10}$ What peasant seeds are is regularly rediscussed collectively within the RSP General Assembly. The latest definition adopted to date (2019) emphasizes that peasant seeds are a 'commons' inscribed in a co-evolution between crops, communities and territories (see https://www.semencespaysannes.org/les-semences-paysannes/qui-sommes-nous.html, Accessed on April 21, 2020). This reframing of peasant seeds as a commons bears witness that RSP claims are no longer focused on a general recognition of farmers' rights over seed exchange and on-farm management, but specifically affirm the rights and practices of the commoners who sustain them. As we shall see below, this evolution is inseparable from the redefinition of action strategies, which aim to move away from commitments with political institutions to give priority to capacity building in the fields.

${ }^{11}$ On the critical potential of the concept 'peasant seeds', see Demeulenaere (2014).
} 
The possibility of aligning all three forms of protest - the defence of organic food, the refusal of GMOs and the defence of seed saving - clearly opened up a new political opportunity (Tarrow 1989).

\section{Looking for intellectual allies, building capacities together with the academic world}

A number of researchers as well as the curator of the national genetic resource collection of wheat were invited to the founding event in Auzeville. This enabled links to be forged with researchers (geneticists, agronomist, science historian, ethnobotanist), who gradually became intellectual allies of the network. They contributed both to the production of valuable epistemic advocacy and to the development of new genetic resources for the growth of peasant seeds (Demeulenaere 2014).

Isabelle Goldringer, a geneticist working at the French National Institute for Agricultural Research (INRA) and specialising in wheat genetics was in charge at the time of following up an experiment on the dynamic management of cultivated biodiversity conducted in agronomic stations. Goldringer played a particular role in the recognition of French farmers' practices as stewards of agrobiodiversity. She directed the first research programme on the contribution of these new farming practices to in situ conservation. The research project submitted to the Genetic Resources Bureau was diplomatically entitled 'Complementarities between on-farm dynamic management of cultivated biodiversity and static conservation of genetic resources' (2005-2007). The project was extended for two years (2007-2009) to focus on the 'Contribution of on-farm dynamic management to the maintenance of biodiversity (through the example of wheat)'. This research culminated in a formal recognition of the RSP as a stakeholder in biodiversity. At least, this is how we interpret the fact that the foundation for research on biodiversity invited the Peasant Confederation to join its Steering Committee in 2009. Véronique Chable, an agronomist also working at INRA, who was involved in organic and biodynamic networks in Brittany even before the creation of RSP, also played a key role in the financing of a series of research programmes which allowed for the development of participatory plant breeding approaches and fostered the integration of farmers' seeds into agrifood networks. ${ }^{12}$

Each of these research programmes opened discussions with researchers, as farmers wanted to have an official status and be recognised in the consortia not just as subcontractors but as full research partners. This demand posed was a problem as there was no space for actors such as legal associations in the official application forms. As a result of these discussions, the farmers involved in the research programmes obtained at least compensation and per diems for participating in meetings. Another bone of contention concerned the ownership of the results of the research projects: negotiations led to the

\footnotetext{
${ }^{12}$ The majority of these programmes were funded by the subsequent European research and innovation agenda (6th and 7th Framework Programme, and lastly H2020). Farm Seed Opportunities, (FP6, 2007-2010), for 'Opportunities for farm seed conservation, breeding and production' - 6 countries, 12 partners; SOLIBAM (FP7, 2010-2014), for 'Strategies for Organic and Low Input Integrated Breeding and Management' - 12 countries, 23 partners; DIVERSIFOOD (H2020, 2015-2019), 'Embedding crop diversity and networking for local high-quality food systems' - 12 countries, 21 partners. A number of research projects have also been funded by the French research agency (ANR): Wheatamix (on mixes of wheat varieties) (2014-2018); BAKERY (Diversity and interactions in a low-input 'Wheat/Human/Sourdough' agro-food ecosystem: towards a better understanding of bakery sustainability) (20142018).
} 
rewriting of consortium agreements by INRA lawyers and the creation of specific Material Transfer Agreements for the genetic resources cultivated on farms within the research projects.

\section{Investing formal institutions in parallel with organising campaigns}

Advocacy and lobbying to change seed regulations continued alongside the research projects. The RSP general delegate Guy Kastler assumed a number of roles including that of member of the Peasant Confederation GMOs and Seed Commission and representative of La Vía Campesina on seed issues. ${ }^{13}$ Steeped in a culture of trade union co-determination, the movement under Kastler's leadership pursued a strategy of sending representatives to committees or bodies where its voice might (even marginally) be heard. When the task was too big for Kastler alone, other people from the RSP were sent out. Their multiple affiliations (to the Peasant Confederation, technical institutes for organic agriculture, environmental NGOs...) could multiply the presence of RSP activists in a variety of bodies, even though the RSP was not formally invited to sit. ${ }^{14}$

Such a strategy proved particularly justified in France as the country historically hosts powerful seed companies (such as Vilmorin) and the seed industry's professional association (GNIS) has structurally acquired a privileged status among lawmakers (Anvar 2008). This is reflected in the fact that representatives of the seed industry are sent to international meetings such as those of the International Treaty on Plant Genetic Resources for Food and Agriculture (ITPGRFA) or UPOV to represent French farmers, while other countries include in their delegations farmer organisations' representatives. Powerful players such as Limagrain (a cooperative group created in 1965 by farmers which has become multinational in the seed sector to the point of joining the top five seed companies worldwide) overtly engage in lobbying activities at the French and EU parliaments.

Sending farmers wherever possible at different levels (national and international) was a way to counterbalance this bias in the interest representation. Investing in a large number of arenas was also a way of obtaining information at the source and promoting connections between different areas (farmers' rights, biodiversity, indigenous and local knowledge, GMOs, etc.), which proved valuable in terms of renewing advocacy. Another way to share resources, informations and issues was by mutualising with other actors of the civil society, constituting the 'social capital' of the organisation (Diani 1997). One of the outcomes of such fruitful collaborations is the 'legal watch on seeds' (veille juridique sur les semences): a newsletter disseminated through a mailing list that tracks legal texts under discussion or pending legal procedures, developed with the NGO Inf'OGM which

\footnotetext{
${ }^{13}$ The Peasant Confederation is a founding member of La Vía Campesina, via the European Peasant Coordination renamed in 2008 as the European Coordination Via Campesina (ECVC).

${ }^{14} \mathrm{RSP}$ members were present in the following committees, under different hats: the steering committee of the Foundation for research on biodiversity (FRB), where there is now a commission on the French actions with the Intergovernmental Science-Policy Platform on Biodiversity and Ecosystem Services (IPBES); CTPS - Permanent Technical Committee for plant breeding, a public body that organised consultation between the French state and professional groups with professional stakes in seeds and plants; the working group 'Seeds and sustainable agriculture' (Semences \& Agriculture durable) at the Ministry of Agriculture; the Economic, Ethical and Social Council within the Higher Council for Biotechnology (Haut Conseil des Biotechnologies, HCB), a consultative body to help French lawmakers regulate GMOs and other kinds of biotechnologies; and at the international level, through La Vía Campesina, the FAO International Treaty on Plant Genetic Resources for Food and Agriculture (ITPGRFA).
} 
has been disseminating critical and independent information on GMOs and biotechnologies since 1999.

When important laws or decisions were being prepared, RSP members could assess the situation from the inside and at the same time oppose resistance from the outside by organising large campaigns involving a wide number of supportive organisations. This was the case in 2011 when the law to implement UPOV 1991 was finally discussed in the French parliament. The campaign Let's sow biodiversity was set up in 2011 with 27 associations involved on different issues: ethical consumption, organic agriculture, social solidarity economy, concerned scientist, etc. At the end of the process, the RSP had won an important battle, in that the law adopted distinguishes farm-saved seeds, for which farmers have to pay a tax, from peasant seeds for which no tax is required. ${ }^{15}$ The RSP took advantage of its capacity to express alternately two types of criticism: radical criticism, from outside the system, and regulatory criticism, from within the system. Alternating between these two forms of criticism as well as intervening in a variety of arenas (biodiversity, farmers' rights, GMO's, etc.) and on various levels have been decisive factors in the success of the RSP in those years.

\section{Abandoning institutions, deserting political arenas, or the scenario of 'conviviality'}

For over fifteen years, the work of the RSP has been divided between grassroots development and advocacy within institutions. However, in the last five years, distrust has emerged with regard to the second arena. As we shall see, the new interest of European and French institutions in the outcome of farmers' breeding activities gave rise to mistrust and fear of distortion.

When the possibility of experimenting marketing of 'heterogeneous material' was presented (EU decision passed in 2014, representing a preliminary step towards marketing of 'populations'), the RSP called upon its members to ascertain whether anyone was interested. As no interest had been expressed, the only marketed populations in France come from French and English breeding research centre, unlike in Italy, as we shall see below. This lack of interest was explained firstly by the fact that a large-scale marketing approach would have been contrary to RSP's idea that seed reproduction should be integrated into (and not separated from) agricultural production. It is indeed generally accepted within the RSP that seeds are too serious a matter to be left to just a few people: everyone should be able and willing to prepare seeds for themselves. Starting to sell or buy peasant seeds in large quantities would mean abandoning one of its founding political principles, i.e. empowering every farmer so that they become able to breed their own locally adapted seeds.

Furthermore, many key members of the RSP feared that behind registration of populations lay the interests of seed corporations suspected of trying to appropriate farmers' genetic innovations. For this reason, the RSP took a critical stance towards the new EU regulation on organic farming approved on 19 April 2018. Along with an accusation against New Breeding Techniques (NBTs) and patents on native traits, it expresses RSP's concern that the new organic farming regulation could ease access by seed companies

${ }^{15}$ Law $n^{\circ} 2011-1843$ of 8 December 2011 on plant variety protection. 
to new genetic material developed by farmers' networks in order to patent genetic information (RSP 2018). The level of distrust is so high that some even question the high success rate of European organisations for peasant seeds in EU calls for proposals: their hypothesis is that European funding has served as a means for Europe of stimulating and ultimately reappropriating peasant innovations for the benefit of plant breeders. Similar scepticism arose when the Permanent Technical Committee for Plant Breeding (Comité Technique Permanent de la Sélection des Plantes Cultivées - CTPS) recently invited the RSP to register as a genetic resource curator.

In addition to the fear that institutions may distort the RSP's political project, another concern is that pursuing research programmes in line with the objectives of the European research and innovation agenda would gradually distance the actions of the RSP from the real needs emerging from local communities.

Another development stems from a change of generation and culture which corroborates a significant trend in social movements, at least in France: newcomers to the RSP come less and less from unions and parties, and even reject these forms of political engagement, considered out-dated. ${ }^{16}$ These new members find the codetermination strategy costly and sometimes even emotionally distressing. The gap between activist cultures was epitomised by a heated dispute in 2016 when the RSP Board of Directors decided against Guy Kastler's opinion to resign together with a number of NGOs from the French High Council for Biotechnology. In their opinion, this body had proved to be biased in favour of pro-GMOs' interests, silencing opponents' voices, which made any opposition ineffective and even uneasy (interview with Board member, March 2018). Kastler, on the contrary, believed that those from the RSP who wanted could resign without provoking a collective resignation of other members and of other NGOs. As a trade unionist, he had a long practice of defending peasants in official bodies where his organisation's voice was in the minority. He argued that the HCB was the only public body dealing with biotechnology where farmers and civil society organisations defending an alternative to the dominant model were represented and where they could achieve some victories. But the disagreement was lively enough to lead to a breaking point. Without going into the details, one should mention as well the commercial agreement established between a member organisation of the RSP and the supermarket group Carrefour which became another bone of contention between the members close to the Confederation paysanne and other members.

When Kastler retired from his role as general delegate of the RSP in 2016, no one was appointed to replace him at this position. Instead, the Board of Directors re-opened discussions on the RSP strategy and modes of organisation by consulting members and convening workshops. Debates within the RSP led to the decision to withdraw from political arenas in favour of field experiments and grassroots empowerment - an orientation endorsed by the General Assembly in December 2017. Some openly criticised the RSP's allegiance to the Peasant Confederation, stating that the RSP had only been created to receive funds that charities could not directly donate to the Peasant Confederation, for they were not allowed to make donations to trade unions. One year later, in December 2018, the General Assembly voted for new by-laws suppressing the special 'founding

\footnotetext{
${ }^{16}$ The last presidential elections in 2017, where traditional political parties have collapsed, and the Gilets jaunes movement of Fall 2018 are two manifestations of the rising distrust of political parties and unions among the French population.
} 
member' status reserved to the Peasant Confederation and to the other three organisations. The political option supported by the Board was to strengthen the social base through practical or legal trainings at the grassroots level and to delegate advocacy and political lobbying to organisations better equipped to do so.

This development recalls the historical trend among feminist movements in Italy in the 1970s, which decided to desert political arenas, considering that these environments where not supportive of women and were infringing their 'right to feel at ease' (Centemeri 2011 , 227). Analysts have argued that feminism in Italy had become 'karstic' - a geological metaphor to express that it was no longer visible but was still flowing under the rocks (until its future resurgence). Similarly, some RSP members called for a shift from oldfashioned 'totalitarian activism' towards a 'hedonist activism' compatible, for example, with a fulfilled family life. At the 2018 general assembly, members joked about 'becoming mycelium' - another metaphor suggesting that the farmers' network would disappear underground. This was a way of asserting that they would prefer to remain both nonlegible and non-governable (Scott 1990, 1998) as was the case at the outset of the RSP, and refused the integration of peasant seeds into state processes. This may be the beginning for the RSP of a 'latency period' (Melucci 1996, cited in Chester and Welsh 2011), during which it will redefine its frame of contention and repertoire of action, to adapt it to the new situation.

\section{The Italian rural seeds network: strengthening technical-scientific expertise to better lobby on policies}

The Rural Seeds Network (hereafter RSR) is an umbrella association created in 2007 which currently comprises about forty legal entities. A few years prior to the official creation of the RSR, some of its key founders had begun to build a tight network of activists aiming to influence political institutions and public agricultural research centres on seed issues. As we did for the French case study, in the following section we discuss the history and structure of the organisation up to the most recent internal debates.

\section{At the origins of the RSR (2000-2006)}

The geographic features and rural culture of Italy have contributed to shape and maintain a wide range of 'traditional plant varieties' (varietà tradizionali) (Berg 2009). Since they are neither stable nor uniform as required, these varieties are not registered in official catalogues and are kept by elderly peasants, mainly in marginal areas remote from agricultural modernisation.

Concerns about these landraces began to emerge during the 1990s. At this time, agronomist Isabella Dalla Ragione, who worked on fruit trees, created the first ever association that identifies and conserves ancient orchards: Arboreal Archeology (Archeologia Arborea). Historian and philosopher Massimo Angelini embarked on a research project on ancient crop varieties, walking throughout the rural areas of the Liguria region. He became a promoter of the Consortium of Quarantina (Consorzio della Quarantina), an association founded in the early 2000s by a committee of local farmers, which aims to preserve and reproduce the Quarantina potato and other local varieties traditionally cultivated in the region. The association headed an inclusive dynamics, which successfully revived these 
landraces on local markets and resulted in food chains supporting the local agricultural economy (Da Vià 2012). During the same period, Peasant Civility (Civiltà Contadina), another non-profit association, was founded to mitigate the loss of genetic biodiversity by promoting small farmer agriculture and organic farming. Alberto Olivucci, an influential member of the association who became its president in 2001, re-centred the association's strategy on seed saving practices: he set up the first national network of gardeners oriented not only on farming species but also on ornamental and wild plants from all over the world.

In July 2000, the above-mentioned people organised a national meeting at Cornale farm in Piedmont. The representatives of the associations met with gene bank curators, gardeners, seed savers and research institutes interested in conservation to discuss how to save, exchange, sell and use local and traditional varieties of fruits and vegetables. This meeting led to the creation of the National Coordination for Rural Preservation and Diffusion of Local Varieties (hereafter Coordination), an informal network of around fifteen members representing associations, small-scale farmers and agricultural research. The Cornale meeting provided a forum for discussion between civil society and public agricultural research institutions (universities, germplasm banks, national research institutes, etc.), which were focused on conventional plant breeding. As Dalla Ragione recalls:

The aim was to maintain a direct connection with the scientific world. At that time, geneticists considered the issue of conserving local varieties from a rather narrow-minded angle. They did not even call them local varieties ... they saw nothing of the surrounding world linked to traditions, experiences, peasant and rural culture. We were the ones who started talking about local varieties, when they talked about genetic resources, understood as raw material to be used [for conventional plant breeding]. (interview, November 2017)

Despite the informal status of the Coordination, it immediately established a link with scientific and political institutions thanks to professional acquaintances of some of its members. Isabella Dalla Ragione and Oriana Porfiri - an agronomist by training who became a farmer cultivating wheat landraces - for example, already collaborated with important national and international research institutes (e.g. the International Plant Genetic Resources Institute ${ }^{17}$ ). Antonio Onorati also played an important role. Until 2015, he was president of the Crocevia International Center (Centro Internazionale Crocevia), an NGO supporting peasants' movements, renowned for its role as international secretariat of the International Planning Committee (IPC) for Food Sovereignty since 2002. Thanks to Onorati's direct links with political institutions, the Coordination submitted to the Ministry of Agricultural, Food and Forestry Policies ${ }^{18}$ the first draft decree implementing EU Directive 98/95/CE on 'conservation varieties' - i.e. those varieties not included in the official catalogue and at risk of genetic erosion (Bocci 2009). However, the draft was not passed in parliament.

Through their institutional connections, these activists sought during this period to lead important legislative processes for the legal recognition of farmers' rights over their own seeds and the protection of local and native varieties. By means of this 'militant legal strategy' (Monsalve Suárez 2013), these activists promoted a political philosophy that was

\footnotetext{
${ }^{17}$ Renamed Bioversity International in December 2006.

${ }^{18}$ Renamed Ministry of Agricultural, Food, Forestry and Tourism Policies (MiPAAFT) in 2006.
} 
completely absent in the approach of farmers' unions and professional associations, as witnessed by one key player:

The Coordination represented a group that was not represented by anyone: those farmers who needed to exchange or sell small quantities of seeds, as small-scale farmers traditionally did in the past. Small-scale farmers were not represented by anyone. (interview, November 2017)

At the start of the new millennium, the main Italian trade unions representing farmers and small and medium-sized farming entrepreneurs (e.g. Coldiretti ${ }^{19}$ and the Italian Farmers Confederation ${ }^{20}$ ) were promoting programmes and policies aligned with the mainstream objectives of food security and agricultural modernisation (Giunta 2019). This may explain why Italian farmers' unions kept out of the Coordination, even after the creation of the RSR.

Two years after the meeting in Cornale, shortage of funds and lack of personal commitment weakened the Coordination project. Only few people remained active. Riccardo Bocci, a young agronomist and researcher at the Overseas Agronomic Institute (IAO) of the Ministry of Foreign Affairs in Florence, was one of them. He organised national and international meetings on seed management and farmers' rights financed by the IAO. In addition, Bocci strengthened cooperation and gained the trust of various activists in the network. His professional and militant commitment played a central role in the creation and development of the RSR.

\section{The creation of the RSR and its early connections with public institutions}

The RSR was founded in 2007. In addition to the above-mentioned associations (Arboreal Archeology, Consortium of Quarantina, Peasant Civility, Crocevia International Center), several other organisations were invited to join: two organic farming associations (the Coordination of Organic Producers of the Tuscany region - CTPB, and the Italian Organic Farming Association - AIAB) and two small farmers' associations (Association for the Protection of the Italian Campaign - ASCl, and Italian Rural Association - ARI). Two main factors underpinned the creation of the RSR. The first was its recognition by political institutions. In 2007, some members of the Coordination established a political dialogue with the Green Party (Partito dei Verdi) in order to present a bill for the implementation of the EU Directive 98/95, finally passed as Law n. 46 of 6 April 2007. A second, more incisive factor was that the same year, an official from the Ministry of Agricultural, Food, Forestry and Tourism Policies (MiPAAFT) put forward a proposal to the Coordination to build a legal multi-representation entity for a three-year funded assignment. This funding involved carrying out activities for the dissemination and the implementation of the Treaty on Plant Genetic Resources for Food and Agriculture (ITPGRFA) ${ }^{21}$ which suggests that the Coordination activists, even though they were part

\footnotetext{
${ }^{19}$ Coldiretti is an agricultural union founded in 1944, with 1.6 million members in 2018.

${ }^{20}$ Italian Farmers Confederation (Confederazione Italiana Agricoltori) is a professional agricultural organisation founded in 1977 , which currently has around 900,000 members.

${ }^{21}$ The International Treaty on Plant Genetic Resources for Food and Agriculture (ITPGRFA) is a comprehensive international agreement pertaining to the conservation, exchange and sustainable use of the plant genetic resources for food and agriculture (PGRFA). Signed in 2001, it established farmers' rights to the protection of traditional knowledge, equitable benefit sharing and the right to participate in decisions regarding the management of PGRFA.
} 

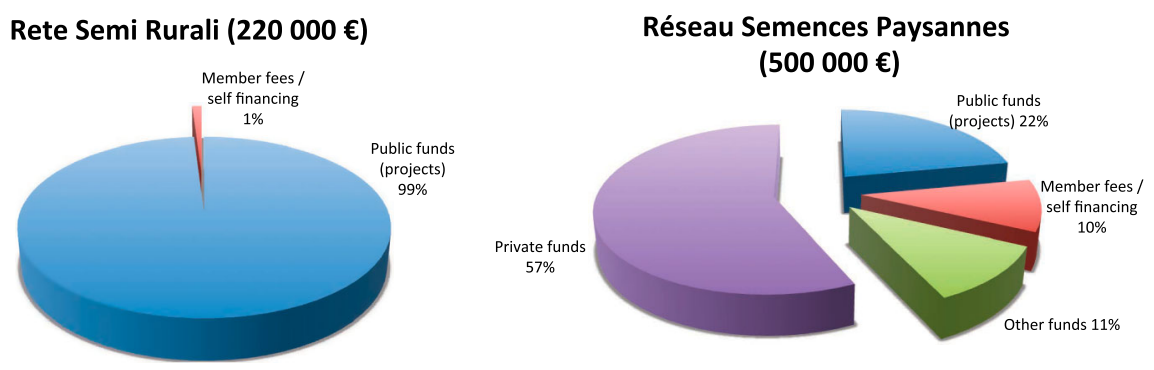

Figure 2. Comparison of sources of funding in the 2 organisations. (source: Bartha 2017).

of a non-formalised entity, were already recognised as the only actors relevant on these issues.

The fairly rapid inclusion of the movement in institutional dynamics was helped by the fact that key actors of the Coordination had strong allies in scientific and political institutions. Furthermore, relations with the institutional world were also driven by the need for RSR to mobilise public financial resources in the absence of funds from private foundations (in contrast with the French RSP, which was partly funded by charities and could remain independent from public institutions, see Figure 2).

The first few years of the RSR's activities have been almost totally financed by national and regional public funds. The MiPAAFT agreement covered merely the RSR administrative expenses as well as the costs of printing technical and promotional material. The region of Tuscany made a small financial contribution, made it possible to construct the building where the RSR Seed House was established (Piersante 2019). Through these activities, the RSR acquired considerable visibility in the eyes of farmers and rural associations. As a sign of this new attractiveness, the RSR registered thirteen new members in 2013, thus doubling its social base within one year.

Meanwhile, the internal governance of the RSR underwent a major transformation during this period. The General Assembly voted for new administrative and political managers. Riccardo Bocci played a significant role in this turnover. Until then, he had been a volunteer for the RSR and worked for the Italian Association of Organic Agriculture as a technical manager for the Solibam project (2010-2014), the first EU project on Plant Participatory Breeding (PPB) for organic farmers. In 2014, the RSR members appointed Bocci as technical director of the network in charge of developing future projects.

From 2014 onwards, European programmes became the main financial resource for RSR (Figure 3). The network has mainly stepped up its activities in relation to the European funding programme for research and innovation Horizon 2020. The Diversifood project (2015-2019, twenty-two partners) contributed to integrate scientific research and on-farm practices, and to spread participatory plant breeding throughout the national territory. Subsequently the RSR continued to focus on sustainable food systems in cereal marketing chains through the CERERE project (2016-2017, thirteen partners).

During these years the RSR committed to a variety of projects, progressively expanding its partnerships. One example is the CAPSELLA project (2016-2018), in which eight partners (including research institutes, universities, private companies and associations) aimed to 


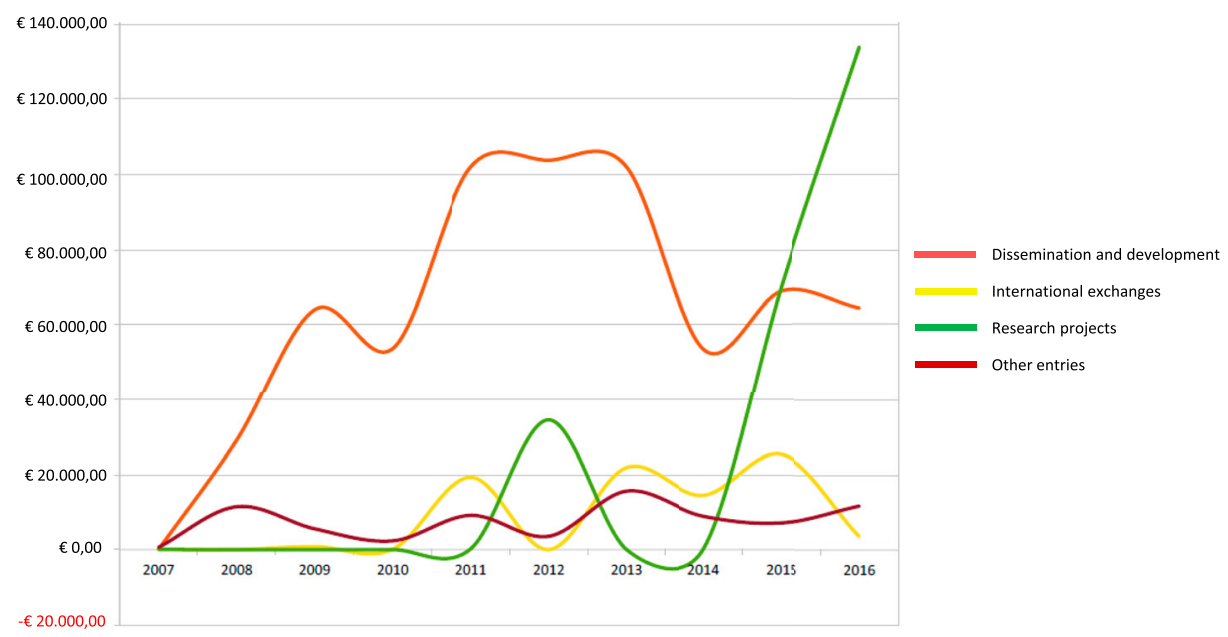

Figure 3. Funds received by the RSR by type of activities, from 2007 to 2016 (Source: RSR 2016).

create a communication tool based on information and communication technologies to support agroecological production models. Dynaversity (2017-2020) relies on an even broader consortium: it involves research institutes and consulting companies specialised in the agribusiness sector, with the idea to work more generally on management systems and governance models for genetic plant conservation, of which farmers practising on farm conservation activities are only a part.

The high success rate in European projects points to the advanced technical skills acquired by the RSR's staff under the leadership of Bocci. In 2017, the National Rural Network $^{22}$ invited the RSR staff to the European conference on Technical Assistance Systems for Agriculture to present them as 'best practice'. Moreover, within only two years, RSR doubled its budget and increased its staff from three to ten workers - mainly agronomists and geneticists.

\section{The scenario of institutionalisation (and commercialisation) at the risk of weakening internal democracy and social base participation}

Over the past few years though, the organisation of collective actions meant to be horizontal and participatory has suffered from the schemes and temporalities dictated by the institutional agenda (short deadlines, consortium agreements, deliverables constraining research activities, etc.). In this context, the Board had to struggle to preserve the principles and procedures of RSR governance, and felt sometimes helpless in the face of the staff increasing autonomy.

Although the RSR's governance seemed to be suffering from technocratic management, the social base of the network was still constantly growing while more and more farmers seek technical assistance and guidance to revive on-farm breeding practices. In order to meet these needs, RSR technicians organised courses and trainings for farmers,

\footnotetext{
${ }^{22}$ The National Rural Network is a MiPAAFT programme that accompanies and integrates the activities related to the development of rural areas for the period 2014-2020.
} 
students, researchers and associations, thus reinforcing the central role of RSR in Italian seed activism.

National governmental and scientific institutions now recognise the political and technical expertise of the RSR. For this reason, the MiPAAFT invited the technical director of RSR to take part in legislative processes or institutional working groups related to seed regulation. The capacities of its staff therefore paved the way for acceptance of the RSR by the agrobiodiversity stakeholders, as evidenced by the technical director:

Our strategy in terms of relations with institutions (regional, national or European) is based on the idea of changing the traditional approach to representation. As far as advocacy is concerned, we have always tried to reach our objectives on the basis of our skills, which may be technical or political. Today, we can see the results of lengthy processes. It will take years to complete these processes, because they are not based on the recognition of our role by others but on our skills. In my opinion, this is the winning model. (interview with Riccardo Bocci, May 2018)

However, when national research institutes adopt public positions on critical issues (e.g. on so-called New Breeding Techniques) or when the government delivers new laws that do not support farmers' rights, the RSR does not promote any press release, protest or collection of signatures. Is it for fear of exposing the organisation to political disputes and of ruining scientific and institutional collaborations? As Kriesi (1996) suggests, the tendency to step away from direct protest actions and to prefer instead institutionalised tactics is a widespread strategy among formalised organisations that tend to professionalise. Nevertheless, the option of staying in the background is hotly disputed within the RSR: some members demand indeed that the network take a stand on heated public issues.

During the 2018 RSR general assembly, members discussed decision-making and representation. The discussion shed light on a weak understanding of seed policies and politics among the majority of members. As a result, the board and a large proportion of members preferred to delegate institutional relations to the technical director, trusting his technical and political expertise. The role of the 'expert' who influences opinions through trust investments more than arguments has long been a topic for discussion (Pellizzoni 2011). At the same time, some members resisted this orientation and argued for the formation of a political delegation composed of representatives appointed to participate in institutional debates. They also denounced the lack of information regarding the activities of the technical director within national and international institutions. They referred to the problem of delegating the political representation to a 'spokesperson of science' (Rodotà and Tallacchini 2010, 863), when social movements should strive to achieve a more democratic construction of advocacy:

We worry about (...) a technocratic approach, which entrusts all its political direction to the technicians. It is the model of classical research and of the dominant paradigm. The problem of representation is not a matter of who attends [such or such meeting] but, as members, we do not know what has been said. There are no reports and no content sharing even though he is speaking on behalf of 40 associations. There is a lack of horizontality. (Farmer member of the Italian Rural Association - ARI, RSR General Assembly 2018)

A significant minority of members challenges the RSR political strategies undertaken by the expert staff. Their disagreement was recently epitomised in the context of the EU Commission implementing decision 2014/150, concerning the temporary experiment 
(mentioned above) providing for marketing 'heterogenous material' (as opposed to uniform and stable varieties) for certain plant species. When it came out, the Technical Director of the RSR argued that the network should seize this opportunity to transform an 'informal seed system' (a common expression in the scientific literature to refer to seed exchanges among farmers that usually take place below the radar of official statistics) into a 'dynamic formal system'. Consequently, the RSR registered five cereal populations bred in the context of Participatory Plant Breeding (PPB) projects. The RSR then publicly declared that the EU Decision 2014/150 brought important recognition for informal seed systems, and progress for agriculture in general as it challenged the dogma of uniformity for the first time (Rete Semi Rurali 2015). Farmers began to market wheat populations obtained within the framework of PPB programmes and celebrated the opening up of the formal seed system to heterogeneous varieties as a result of the innovative collaboration made possible by RSR between farmers and scientists. In 2017, two RSR members sold 18 quintals of 'Solibam Floriddia' and 15 tonnes of 'Solibam Li Rosi' two populations of bread wheat named after the European research project and after the organic farmers who had dedicated time, care and hundreds of hectares of farmland for field trials (Da Vià 2015; Bussi et al. 2017). Yet, despite certain precautionary provisions regarding property rights, ${ }^{23}$ some RSR members (who share the dominant viewpoint within the French movement) expressed strong disagreement with the converging of the collective outcome of peasant practices (the so-called informal seed system) with the dominant seed system (the so-called formal seed system). In particular, they argue that the registration of peasant seeds can create a schism between entrepreneur farmers only motivated by rapid access to these newly bred populations, and militant farmers critical of the logic of the formal seed system, including the many constraints it imposes (phytosanitary rules, storage spaces and financial investments...) and the forms of exclusion it creates.

In autumn 2018, the EU Commission decided to extend the experimentation period for the marketing of heterogeneous material until 2021 (Decision 2018/1519/UE) in order to better prepare future regulations on the matter. At the same time, the new EU regulation on organic farming (approved on 19 April 2018 and to be implemented after 2021) provided for the possibility of marketing 'organic heterogeneous material.' It was no coincidence that these two EU decisions were reached at the same time. They were the result of a parallel approach in which some people believe that RSR has played a strategic role. As they argue, 'one of the main results of SOLIBAM [project] was that it gave impetus to a process of opening up European legislation on seeds with respect to the marketing of populations' (Bussi et al. 2017, 26; our translation). Moreover, the positive results of the research programmes allow RSR staff to attend expert groups and standing committee meetings to support decision-making processes among the political institutions.

As a result of this expertise-reinforcement strategy, the RSR is becoming increasingly involved in 'deliberative participation' processes (Pellizzoni 2013), particularly at the

\footnotetext{
${ }^{23}$ Inspired by the Open Source Seed Initiative - an experiment born in the US few years ago, which has devised a seed marketing system based on Open Source principles (Kloppenburg 2014) - the RSR is experimenting a new form of plant variety rights. At this stage it is not (yet) a registered brand, but a tool for the recognition of the collective innovation work that provides benefit sharing principles. Even though it is not legally binding, the message on the label on the seedlots on sale contains a pledge that every farmer buying these seeds is free to continue and make available the results of the population selection processes, and commits himself not to limit the use of the seeds purchased and its derivatives through patents or forms of intellectual property.
} 
European level. However, representation is not entrusted to members elected within the movement but to the technical staff, who are steadily gaining leadership in RSR's decisionmaking and political strategies. To go back to Kriesi's framework, the RSR illustrates a trajectory of institutionalisation, ${ }^{24}$ which is doubled by a re-orientation towards service activities (open to anybody and not only the members), suggesting the coexistence of a commercialisation scenario. In the process, the social base tends to be divided between farmers interested in the professional services of RSR technicians, and politicised associations that denounce the distortion of their original project and its core values (farmers' rights, agrobiodiversity ...).

\section{Conclusion: in, or out, or both?}

The two movements analysed here have undoubtedly played a significant role in biodiversity management policies and seed regulations, both at national and international levels. However, they have built different strategies and relationships with political and research institutions. They position themselves differently with regard to these arenas, accepting to different degrees their status as official stakeholders.

As far as the RSP is concerned, influencing government policies through lobbying or participation in various bodies has for a long time alternated with strong opposition campaigns largely supported thanks to the social capital network of the movement (Diani 1997). The RSP's relationship with political institutions could therefore be interpreted as oscillating between regulatory criticism and contestation criticism (Chateauraynaud et al. 2010). However, the 2017 RSP general assembly decided to move away from political arenas and abandon political advocacy in order to prioritise farmer members' training in the field and practical support. This withdrawal stems above all from a deep distrust of biotechnology regulation arenas where the involvement of farmers would only serve to legitimise (already taken) decisions. Participating in these biased political spaces feeds a fear of exhaustion. This withdrawal may also be considered as a symptom of a change of political culture among activists characterised by a rejection of unionist forms of mobilisation, their totalitarian dimension (in the sense that involvement should take precedence over personal life), and their delegative forms of representation which for some may foster a sense of being manipulated.

A majority of RSP members currently interpret the development of new biotechnologies and registration for the marketing of peasant seeds in terms of expropriation of genetic material bred in farmers' fields for the benefit of conventional breeders. More generally, there is little support for the strategy of expanding the customer base for peasant seeds. For most RSP members, the inclusion of peasant seeds in the socio-economic dynamics of the market would distort the political project pursued by the movement, which aims to recreate communities of practices sharing seeds, knowledge, know-how and new types of solidarity (between humans and plants) and ultimately to enact a farming utopia which respects people and the environment. In this respect, the experience

\footnotetext{
${ }^{24}$ della Porta and Diani $(1999,145)$ offer a quite similar analysis, with the notion of 'professional social movement organisation'. According to them, these types of organisation are characterised by a low rate of participation by the associative base in decision-making processes and organisational policies; professional staff who largely determine the positions adopted by the organisation towards various issues; and leaders who rely more on their reputation as technical experts on specific matters than on mass mobilisation (see also McCarthy and Zald 1987 [1973]).
} 
of organic farming, which according to its pioneers has lost its soul after it was recognised by the French state and became a mass-market phenomenon, acts as a constant reminder. As a consequence of what can be critically referred to as a 'temptation of purity', the RSP has limited its legal claims to securing the right to exchange small quantities of seeds between farmers and within gardeners' groups. It remains attentive to the legal context, however, through its 'legal watch', a valuable information tool providing updates on seeds and farmers' rights policies, bearing in mind that seed laws and new breeding technologies may not evolve in their favour. However, its ultimate aim is to preserve or create spaces for the development of small-scale practices for which they can establish their own internal rules. This is probably the meaning underlying the motto that has recently appeared in the network, 'Peasant Seeds, a Commons', echoing the Ostromian theories of the commons, which have shed light on the collective forms of natural resource management beyond the state, and which have been widely commented on and recently reappropriated by new environmentalisms (Centemeri 2018; Demeulenaere 2018). The drawback of such withdrawal is a loss of influence on the system which sets boundaries for their action. Political lobbying has been delegated to other organisations, such as the Peasant Confederation, even though the successes of the RSP over the past decade have relied on a combination of the two approaches - advocacy (from within, and if necessary, from outside, through protest actions) and grassroots action.

In contrast, the RSR has always established or taken advantage of deliberative participatory processes closely embedded in institutions. By presenting bills and being present at consultation tables, technical committees, etc., it has opted for changing the system from within. This organisation has promoted policies both nationally and internationally allowing farmers to market seeds that are produced or bred on farms. However, not all members support this political vision; instead it is at the centre of a conflict, which ultimately leads to the segmentation of the movement. At the heart of the dispute is a different understanding of the claims and values that should unite the movement with regard to the recognition of farmers' rights and seed management practices. As far as organic farming entrepreneurs are concerned, the achievement of a legal framework which grants them the opportunity to market seeds produced on-farm is considered as a step towards the recognition of on-farm breeding practices as well as a means of meeting the growing demand for certified organic seeds. Such an option is not acceptable for those (peasants and activists) who are more small-scale agriculture oriented. For them, marketing on conventional markets entails an acceptance of a number of limitative norms (phytosanitary standards, storage spaces, registration, etc.), to which only agricultural entrepreneurs can adapt, and which exclude smaller farmers. They ask their organisation to follow political objectives that guarantee 'collective rights' for sustainable seed management.

In a context in which peasant seeds are being recognised, particularly in European policies, seed movements in Europe are evolving differently. There is no one-way institutionalisation. Neither is there a single teleological trajectory for the institutionalisation of alternatives.

After having obtained institutional recognition and the right of peasants to exchange their seeds, the French example now shows an attempt to resist integration into state and community policies, whereas the Italian one reaps the fruits of its long-term embeddedment in seed regulation arenas. These divergences stem from different collective 
conceptions of the political cause and different activist landscapes, but also from contrasted governance methods. The Italian movement has followed the technical director's orientations, whose leadership is based on his multifaceted expertise, whereas in the case of France, the general assembly has decided to take over leadership after the general delegate's retirement who had imbued up to then the movement's strategy with a strong unionist culture.

This comparison between two approaches to seed activism leads us to two concluding remarks. Firstly, the dialectic relationship between 'the instituting' and 'the instituted', which constitutes a traditional analytical framework in the sociology of social movements, may completely miss the dynamics that specifically refuse to comply with institutions. The renewed focus of researchers on 'instituting praxis' is without doubt important (Dardot and Laval 2019). Nevertheless, social scientists should remain attentive to what happens 'below the radar', 'beyond what the state sees' (Scott 1998), because this is precisely where new forms of life are invented or tried out. Secondly, even if they are not intended to affect the system directly, these invisible experiments should be considered as political. Seed activism is part of a general trend in which ordinary practices, such as gardening, tinkering, etc. are given a political significance (Baudry 2012). This is an invitation for the social sciences to expand their understanding of what politics is, to include what has been referred to as infra-politics. The question remains as to whether or not the deployment of politics beyond its traditional arena should involve a total withdrawal and disconnection from political structures.

\section{Acknowledgments}

We are grateful to the members of the two organisations studied here, for the time and interest they have dedicated to this research, either through interviews or through critical reviewing of our first drafts. Karine Peschard, Edouard Morena, Stefano Mori, and three anonymous reviewers have also provided us valuable comments which have greatly helped us maturing the analysis.

\section{Disclosure statement}

No potential conflict of interest was reported by the author(s).

\section{Funding}

This work was supported by Agence Nationale de la Recherche [grant number ANR-15-CE21-0006-09 IDAE].

\section{References}

Anvar, S. L. 2008. "Semences et droit. L'emprise d'un modèle économique dominant sur une réglementation sectorielle." PhD dissertation, Université Paris 1-Panthéon Sorbonne, France.

Balázs, B., A. Smith, G. Aistara, and G. Bela. 2015. WP 4: case study report: Transnational Seed Exchange Networks, TRANSIT: EU SHH.2013.3.2-1.

Bartha, B. 2017. 'National Seed networks in Central and Eastern Europe.' Presentation at the workshop on Community Seed Banks, 21 September 2017. Program Diversifood. Accessed April 12, 2019. http://www.communityseedbanks.org/media/diversifood_meeting_csb_21_9.2017_praes_ psr.pdf. 
Baudry, S. 2012. "Reclaiming Urban Space as Resistance: The Infrapolitics of Gardening." Revue Française D'études Américaines 131: 32-48.

Berg, T. 2009. "Landraces and Folk Varieties: A Conceptual Reappraisal of Terminology." Euphytica 166: 423-430.

Bocci, R. 2009. "Seed Legislation and Agrobiodiversity: Conservation Varieties." Journal of Agriculture and Environment for International Development 103 (1/2): 31-49.

Bocci, R., and V. Chable. 2009. "Peasant Seeds in Europe: Stakes and Prospects." Journal of Agriculture and Environment for International Development 103 (1/2): 95-130.

Borras, S.M., Jr, and J. C. Franco. 2009. Transnational Agrarian Movements Struggling for Land and Citizenship Rights. Working Paper 323. Brighton: Institute of Development Studies.

Bussi, B., R. Bocci, S. Ceccarelli, M. Petitti, and S. Benedettelli. 2017. "La frontiera del miglioramento genetico dei cereali per l'agricoltura biologica: il materiale eterogeneo." dal Seme 2 (17): 19-29.

Callon, M., P. Lascoumes, and Y. Barthe. 2009. Acting in an Uncertain World. An Essay on Technical Democracy (translated from French by G. Burchell). Cambridge, MA: MIT Press.

Carrascosa, M. 2003. Enquêtes sur les expériences et savoir-faire 'Semences paysannes, biologiques et biodynamiques' dans les campagnes françaises. Brens: Réseau Semences Paysannes.

Ceccarelli, S., and S. Grando. 2007. "Decentralized-participatory Plant Breeding: an Example of Demand Driven Research." Euphytica 155 (3): 349-360.

Centemeri, L. 2011. "Retour à Seveso. La complexité morale et politique du dommage à l'environnement." Annales. Histoire, Sciences Sociales 66 (1): 213-240.

Centemeri, L. 2018. "Commons and the new Environmentalism of Everyday Life. Alternative Value Practices and Multispecies Commoning in the Permaculture Movement." Rassegna Italiana di Sociologia 59 (2): 289-314. doi:10.1423/90581.

Chateauraynaud, F., A. Bernard de Raymond, M.-A. Hermitte, and G. Tétart. 2010. Les OGM entre régulation économique et critique radicale. Paris: GSPR -EHESS.

Chester, G., and I. Welsh. 2011. "Latency Period." In Social Movements. The key Concepts, 107-108. London: Routledge.

Corrado, A. 2010. "New Peasantries and Alternative Agro-Food Networks: The Case of Réseau Semences Paysannes." In From Community to Consumption: New and Classical Themes in Rural Sociological Research, edited by A. Bonanno, H. Bakker, R. Jussaume, Yoshio Kawamura, and M. Shucksmith, 17-30. Bingley: Emerald.

Dardot, P., and C. Laval. 2019. Common. On Revolution in the 21st Century. Translated by Matthew MacLellan. London: Bloomsbury.

Da Vià, E. 2012. "Seed Diversity, Farmers' Rights, and the Politics of Re-peasantization." International Journal of Sociology of Agriculture and Food 19 (2): 229-242.

Da Vià, E. 2015. "Food Sovereignty in the Fields: Seed Exchange and Participatory Plant Breeding of Wheat Landraces in Italy." In Food Sovereignty in International Context: Discourse, Politics and Practice of Place, edited by A. Trauger, 195-211. Abingdon: Routledge.

Dawson, J. C., P. Rivière, J.-F. Berthellot, F. Mercier, P. de Kochko, N. Galic, S. Pin, et al. 2011. "Collaborative Plant Breeding for Organic Agricultural Systems in Developed Countries." Sustainability 3 (8): 1206-1223.

della Porta, D., and M. Diani. 1999. Social Movements: An Introduction. Oxford: Blackwell Publishing.

Demeulenaere, E. 2014. "A Political Ontology of Seeds: The Transformative Frictions of a Farmers' Movement in Europe." Focaal. Journal of Global and Historical Anthropology 69: 45-61.

Demeulenaere, E. 2018. "Free our Seeds!' Strategies of Farmers' Movements to Reappropriate Seeds." In The Commons, Plant Breeding and Agricultural Research. Challenges for Food Security and Agrobiodiversity, edited by F. Girard, and C. Frison, 210-225. London: Routledge.

Diani, M. 1997. "Social Movements and Social Capital: A Network Perspective on Movement Outcomes." Mobilization: An International Quarterly 2 (2): 129-147.

Dutfield, G. 2018. "Farmers, Innovation and Intellectual Property. Current Trends and Their Consequences for Food Security." In The Commons, Plant Breeding and Agricultural Research. 
Challenges for Food Security and Agrobiodiversity, edited by F. Girard, and C. Frison, 21-38. London: Routledge.

Edelman, M., and S. M. Borras, Jr. 2016. Political Dynamics of Transnational Agrarian Movements, Agrarian Change \& Peasant Studies. Nova Scotia: Fernwood Publishing.

Giddens, A. 1990. The Consequences of Modernity. Cambridge: Polity.

Giunta, I. 2019. La Vía Campesina para la soberanía alimentaria. Quito: Editorial IAEN.

Heller, C. 2002. "From Scientific Risk To Paysan Savoir-Faire: Peasant Expertise in the French and Global Debate Over GM Crops." Science as Culture 11 (1): 5-37.

Kloppenburg, J. 2014. "Re-purposing the Master's Tools: The Open Source Seed Initiative and the Struggle for Seed Sovereignty." Journal of Peasant Studies 41 (6): 1225-1246.

Kriesi, H. 1996. "The Organizational Structure of New Social Movements in a Political Context." In Comparative Perspectives on Social Movements: Political Opportunities, Mobilizing Structures, and Cultural Framings, edited by D. McAdam, J. McCarthy, and M. Zald, 152-184. Cambridge: Cambridge University Press.

Martínez-Torres, M. E., and P. M. Rosset. 2010. "La Vía Campesina: The Birth and Evolution of a Transnational Social Movement." Journal of Peasant Studies 37 (1): 149-175.

McCarthy, J. D., and M. N. Zald. 1987. "The Trend of Social Movements in America: Professionalization and Resource Mobilization." In Social Movements in an Organizational Society, edited by M. N. Zald, and J. D. McCarthy, 337-391. New Brunswick, NJ: Transaction.

McMichael, P. 2008. "Peasants Make Their Own History, But Not Just as They Please ... ." Journal of Agrarian Change 8 (2-3): 205-228.

Melucci, A. 1996. Challenging Codes: Collective Action in the Information Age. Cambridge: Cambridge University Press.

Monsalve Suárez, S. 2013. "The Human Rights Framework in Contemporary Agrarian Struggles." Journal of Peasant Studies 40 (1): 239-290.

Morena, E. 2015. "Words Speak Louder Than Actions: The 'Peasant' Dimension of the Confédération Paysanne's Alternative to Industrial Farming." Journal of Peasant Studies 42 (1): 45-71.

Neveu, E. 2015. Sociologie des mouvements sociaux. Paris: La Découverte.

Pellizzoni, L. 1999. "Reflexive Modernization and Beyond. Knowledge and Value in the Politics of Environment and Technology." Theory, Culture and Society 16 (4): 99-125.

Pellizzoni, L. 2011. "The Politics of Facts: Local Environmental Conflicts and Expertise." Environmental Politics 20 (6): 765-785.

Pellizzoni, L. 2013. "Une idée sur le déclin : Évaluer la nouvelle critique de la délibération publique." Participations 6 (2): 87-118.

Piersante, Y. 2019. "Le sementi dei nuovi movimenti agragri. Le Reti per la gestioni dell'agrobiodiversità in Francia e Italia." PhD dissertation, University of Calabria, Italy.

Rete Semi Rurali. 2015. Guida ai sistemi sementieri, a cura di Bocci R. and Galluzzi G., RSR.

Rete Semi Rurali. 2016. Activity Report 2015, General Meeting.

Rodotà, S., and M. Tallacchini. 2010. Ambito e fonti del biodiritto. Milan: Giuffrè Editore.

RSP. 2018. La commercialisation de "matériel hétérogène ", une avancée pour les semences paysannes? Accessed April 12, 2019. http://ressources.semencespaysannes.org/docs/note_eclairage_ materiel_heterogene.pdf.

Scott, J. C. 1990. Domination and the Arts of Resistance: Hidden Transcripts. New Haven: Yale University Press.

Scott, J. C. 1998. Seeing Like a State: How Certain Schemes to Improve the Human Condition Have Failed. New Haven: Yale University Press.

Tarrow, S. 1989. Power in Movement: Collective Action, Social Movements and Politics. Cambridge: Cambridge University Press.

Topçu, S., G. Gourgues, and S. Rui, eds. 2013. Participations 6, Sept.-Oct. 2013, Special issue: 'Critique de la participation et gouvernementalité'.

Van der Ploeg, J. D. 2010. "The Peasantries of the Twenty-First Century: The Commoditisation Debate Revisited." Journal of Peasant Studies 37 (1): 1-30. 
Elise Demeulenaere is an environmental anthropologist at the French National Centre for Scientific Research (CNRS), currently working within the Centre Alexandre Koyré, Paris. Since 2005 she has been following as an engaged researcher the French Réseau Semences Paysannes.

Yvonne Piersante defended in 2019 a PhD in rural sociology at the University of Calabria (UNICAL, Italy), prepared under the co-supervision of Alessandra Corrado, and Elise Demeulenaere during her research periods in France. She proposed a comparative analysis of seed movements in Italy and France. She has been for seven years a seed activist in the Rete Semi Rurali. Since 2012 she is in the Board of Directors of Crocevia. 